\title{
Rumen Fermentation and Microbial Protein Synthesis of Bali Cattle Heifers (Bos sondaicus) Fed Ration Containing Different Energy Protein Level
}

\author{
N. N. Suryani ${ }^{1 *}$, I. W. Suarna ${ }^{2}$, I. G. Mahardika ${ }^{1}$ and N. P. Sarini ${ }^{3}$ \\ ${ }^{1}$ Laboratory of Animal Nutrition \& Tropical Forage Science, Animal Husbandry Faculty, University of Udayana \\ ${ }^{2}$ Tropical Forage Research and Development Centre, University of Udayana \\ ${ }^{3}$ Laboratory of Breeding and Molecular Biology, Animal Husbandry Faculty, University of Udayana \\ * Corresponding email: mansuryanifapet@unud.ac.id
}

\begin{abstract}
The purpose of this study was to determine the effect of energy and protein levels on rumen fermentation, microbial protein synthesis of Bali cattle heifers. The study was conducted in Petang Village, Badung Regency, Province of Bali Indonesia on 12 Bali cattle heifers with initial body weight 193,67 $\pm 22,55 \mathrm{~kg} / \mathrm{head}$. The treatment given is four types of ration consists of different level of metabolizable energy (ME) and crude protein (CP): ME $2051.41 \mathrm{kcal} / \mathrm{kg}: 12.04 \%$ CP (Treatment A); ME $2107.79 \mathrm{kcal} / \mathrm{kg}: 13.05 \%$ CP (Treatment B); ME $2194.06 \mathrm{kcal} / \mathrm{kg}: 14.04 \%$ CP (Treatment C) and ME $2294.23 \mathrm{kcal} / \mathrm{kg}: 15.09 \%$ CP (Treatment D). Variables measured: nutrient intake, rumen fermentation, microbial protein synthesis and growth performance of Bali cattle heifer age of 18 month. This research was a randomized block design. The results showed that increase in $\mathrm{ME}$ to $2294.23 \mathrm{kcal} / \mathrm{kg}$ and $15.09 \% \mathrm{CP}$ significantly ( $\mathrm{P}<0.05$ ) increased energy intake to $17,880.57 \mathrm{kcal} / \mathrm{day}$ and protein intake $686.56 \mathrm{~g} / \mathrm{day}$. Rumen fermentation was also highest $(\mathrm{P}<0.05)$ in treatment $\mathrm{D}$ seen from total VFA, propionic acid and butyric acid respectively $170.32 \mathrm{mMol}, 28.52 \mathrm{mMol}$ and $13.70 \mathrm{mMol}$. While acetic acid, methane and NGR significantly decreased ( $\mathrm{P}<0.05)$ respectively $57.77 \mathrm{mMol}, 18.38 \mathrm{mMol}$ and 3.07 . This resulted in the highest rumen microbial protein synthesis in treatment D which was $562.06 \mathrm{~g} /$ day so that it was able to produce the highest $\mathrm{ADG}$ too, which was $0.42 \mathrm{~kg} /$ day. This study concluded that giving rations containing ME $2294.23 \mathrm{kcal} / \mathrm{kg}$ and $15.09 \% \mathrm{CP}$ increased rumen fermentation and microbial protein synthesis, resulting in the highest growth compared to lower levels.
\end{abstract}

Key words: Bali cattle heifer, energy-protein level, microbial protein synthesis, rumen fermenttion

\section{INTRODUCTION}

Bali cattle are indigenous breed. Generally, rearing of cattle in Indonesia are traditional with the provision of forage feed depending on availability at that time and regardless of the standard nutrient requirements. This is due to fluctuating forage supplies that are affected by the season. So, the productivity of the animal not in accordance with their genetic potential. Rumen microbes are highly dependent on the type of feed given. Normally, most of the food protein will pass through ammonia pools before it is used for microbial protein synthesis in the rumen. (Hristov et al., 2004).

Microbial protein synthesis occurs by using nitrogen from protein degradation in the rumen together with free amino acids, peptides and ammonia from amino acid deamination. Excess rumen ammonia can be caused due to the high content of degradable rumen (RDP) protein in feed. Rumen ammonia enters the bloodstream through the epithelium of the rumen wall so that the concentration of urea nitrogen in the plasma increases (Hristov et al., 2004).
If the availability of nitrogen exceeds the need for rumen microorganisms, this excess will be converted to ammonia. The ammonia formed is then absorbed through the rumen wall epithelium and taken to the liver and converted to urea then excreted through the renal or milk production (Migliano et al., 2016). Dry matter intake (DMI) is affected by protein or nitrogen intake. The protein content in the feed is partially degraded in the rumen and the rest passes as a protein bypass into the abomasum and small intestine, broken down into amino acids and small peptides then absorbed into the blood systems.

Ammonia utilization in the rumen is intrinsically related to carbohydrate availability (Karsli and Russell, 2001). When the ratio of available energy or fermentable organic matter to protein or nitrogen is optimized, so the yield of microbial protein synthesis produced in the rumen is maximized. The balance of nitrogen and energy in the ration is very important to obtain the maximum efficiency of microbial synthesis. Microbial protein synthesis of Bali cattle vary widely from $552.21 \mathrm{~g} / \mathrm{d}$ with ration contain $20 \%$ rice straw $+25 \%$ Gliricidia sepium $+15 \%$ 
elephant grass $+10 \%$ calliandra $+30 \%$ concentrate (Suryani et al., 2019). The advantage of ruminants is that they are able to utilize low quality feed, but cause problems in the efficiency of nitrogen utilization. The low of growth is caused not only by genetic factors but also due to lack of feed and unbalanced nutrition of the feed (Bhatti et al., 2007). The major factor that affecting the overall amino acid requirement of ruminants is the efficiency of microbial protein synthesis in the rumen. Microbial protein can contribute $70-80 \%$ amino acids for ruminants (Chumpawadee et al., 2006). The contribution of amino acids from these rumen microbes can even reach 90\%. Proteins derived from rumen microbes constitute two thirds of the amino acid sources needed by ruminants. The availability of protein and energy is the most influential factor in microbial protein synthesis (Pathak, 2008).

Synchronization of rumen available protein and energy is one of the conceptual methods to increase the efficiency of utilization of nutrients by the ruminants (Chumpawadee $e t$ al., 2006). This research was conducted to study the rumen fermentation, microbial protein synthesis and performance of Bali cattle heifers age of 18 moths old by synchronize energy and protein ration.

\section{MATERIALS AND METHODS}

\section{Cattle}

The study used 12 of Bali cattle heifer of 18 month with average body weight $193.42 \pm$ $18.13 \mathrm{~kg}$. Each heifer reared in individual cages. Given feed consists of forages and concentrates. Concentrate feed was given in the morning. While forage given fresh after concentrate feed. The composition of the ration is presented in Table 1 and the nutrient content of the ration in Table 2.
Table 1. The composition of the ration treatment of Bali cattle heifers age of 18 months

\begin{tabular}{lcccc}
\hline \multirow{2}{*}{ Composition } & \multicolumn{4}{c}{ Treatments } \\
\cline { 2 - 5 } & $\mathrm{A}$ & $\mathrm{B}$ & $\mathrm{C}$ & $\mathrm{D}$ \\
\hline Concentrate & 39.0 & 32.0 & 37.0 & 35.0 \\
Soybean meal & 2.0 & 3.25 & 4.0 & 9.1 \\
Urea & 0.3 & 0.8 & 1.0 & 0.9 \\
Molasses & 0.0 & 3.0 & 4.0 & 4.0 \\
King grass & 58.2 & 59.7 & 51.7 & 48.0 \\
Coconut oil & 0.0 & 0.75 & 1.8 & 2.5 \\
Vitamin/Mineral & 0.5 & 0.5 & 0.5 & 0.5 \\
\hline \multicolumn{1}{c}{ Total } & 100.0 & 100.0 & 100.0 & 100.0 \\
\hline
\end{tabular}

\section{Design of Experiments}

Experiments using a randomized block design. The heifer cattle group treated with 4 different weight as replication. The treatment given is four types of ME: CP levels of ration: ME $2051.41 \mathrm{kcal} / \mathrm{kg}: 12.04 \%$ CP; ME 2107.79 $\mathrm{kcal} / \mathrm{kg}$ : $13.05 \% \quad$ CP; ME $2194.06 \mathrm{kcal} / \mathrm{kg}$ : $14.04 \% \mathrm{CP}$ and ME $2294.23 \mathrm{kcal} / \mathrm{kg}: 15.09 \% \mathrm{CP}$ respectively as treatment $\mathrm{A}, \mathrm{B}, \mathrm{C}$ and $\mathrm{D}$.

\section{Weight gain}

Bali cattle heifer weighing done every two weeks. Cattle's weight gain was the difference between final body weight and the initial body weight. Daily live weight gain is a weight gain during the study divided by the length of the study.

Dry matter, organic matter and nutrient intake dry matter $(\mathrm{DM})$, organic matter $(\mathrm{OM})$, and nutrient intake.

DM Intake obtained by reducing the dry matter gave with the rest of it.

$\mathrm{OMI}=$ total ration intake $\mathrm{x} \%$ Dry Matter $\mathrm{x} \%$ OM $\mathrm{CPI}=$ total ration intake $\mathrm{x} \%$ Dry Matter $\mathrm{x} \% \mathrm{CP}$ $\mathrm{CFI}=$ total ration intake $\mathrm{x} \%$ Dry Matter $\mathrm{x} \% \mathrm{CF}$

Table 2. The nutrient content of ration of Bali cattle heifers age of 18 months

\begin{tabular}{lcccc}
\hline \multirow{2}{*}{ Nutrient of ration } & \multicolumn{4}{c}{ Treatments } \\
\cline { 2 - 5 } & $\mathrm{A}$ & $\mathrm{B}$ & $\mathrm{C}$ & $\mathrm{D}$ \\
\hline Crude Protein (\%) & 12.04 & 13.05 & 14.04 & 15.09 \\
ME (kcal/kg) & 2051.41 & 2107.79 & 2194.06 & 2294.23 \\
Crude Fiber (\%) & 20.81 & 20.61 & 19.02 & 17.66 \\
Ether Extract (\%) & 10.15 & 10.97 & 12.84 & 13.55 \\
Calcium (\%) & 1.43 & 1.29 & 1.37 & 1.30 \\
Phosphor (\%) & 0.56 & 0.54 & 0.59 & 0.54 \\
\hline
\end{tabular}




\section{Rumen Fermentation Products}

The parameters measured were rumen fermentation products i.e. $\mathrm{pH}$, concentration of $\mathrm{N}-\mathrm{NH}_{3}$, Total VFA and VFA partial i.e. acetic acids, propionic acids and butyric acids. Four hours after feeding, ruminal fluid was taken using a stomach tube and using a $\mathrm{pH}$ meter directly measured for its $\mathrm{pH}$. $\mathrm{N}_{-} \mathrm{NH}_{3}$ levels were determined by Spectrophotometer according to Solórzano (1969). The total of VFA and VFA partial were analyzed by Gas Chromatography (AOAC, 1990).

\section{Microbial Protein Synthesis}

Microbial protein synthesis was analyzed according Chen and Gomes (1995):

- Digestible Organic Matter in Rumen/DOMR $(\mathrm{kg} / \mathrm{d})=$ Organic Matter $\mathrm{x}$ Organic Matter digestibility x 0.65

- Microbial Nitrogen $(\mathrm{MN})=32 \mathrm{~g} / \mathrm{kg}$ DOMR

- Microbial Protein Synthesis/MPS (g/d) = MN x 6.25

- Purine absorption $(\mathrm{mMol} / \mathrm{d})=\mathrm{MN}: 0.727$

- Purine derivates excretion $(\mathrm{mMol} / \mathrm{d})=$ 0.85 purine absorption $+0.385 \mathrm{x} \mathrm{W}^{0.75}$

The number of protozoa is calculated based on the methods of Ogimoto and Imai (1981)

\section{Data Analysis}

The data obtained in this study analyzed by analysis of variance. Between treatments, if the results were significantly different $(\mathrm{P}<0.05)$, the analysis followed by orthogonal contrast test at 5\% level according to Steel and Torrie (1995).

\section{RESULTS AND DISCUSSION}

\section{Nutrient Intake}

Dry matter and organic matter intake of Bali cattle heifer in all treatments showed no significant different $(\mathrm{P}>0.05)$. Energy intake of heifers treated with treatment $\mathrm{B}, \mathrm{C}$ and $\mathrm{D}$ respectively $9.61 \%, 5.56 \%$ and $11.97 \%$ significantly higher $(\mathrm{P}<0.05)$ than the treatment A. Protein intake also increases with increasing energy and protein content in rations. The results of this study indicate that Bali cattle heifers treated with $\mathrm{B}, \mathrm{C}$ and $\mathrm{D}$ resulted in increased protein intake by $10.97 \%, 10.10 \%$ and $15.02 \%$ respectively compared to treatment $A$. In line with Schwab and Broderick (2017) that increasing dietary crude protein content may raise ruminal fermentation, which can result in a higher dry matter intake (DMI). The results of rumen fermentation as shown in Table 4 show a marked increase $(\mathrm{P}<0.05)$ with an increase in energy and protein levels. Increased energy ration will significantly improve nutrient digestible. High energy intakes of heifer have no negative effect on the development of mammas and may even have improved growth. Although increased growth rates during the post-puberty period have no effect on milk production (Lohakare et al., 2012). Increased energy intake in the treatment of $\mathrm{B}, \mathrm{C}$, and D is not only caused by increased energy digestibility, but also due to higher energy ration content. Heifers more efficiently utilizes nutrients when fed with $2200-2300 \mathrm{kcal} / \mathrm{kg}$ and $14-15 \%$ protein seen from daily weight gain and FCR (Tabel 6).

Table 3. Nutrient intake (g/day) of Bali cattle heifers age of 18 months

\begin{tabular}{|c|c|c|c|c|c|}
\hline \multirow{2}{*}{ Variables } & \multicolumn{4}{|c|}{ Treatments } & \multirow{2}{*}{ SEM } \\
\hline & $\mathrm{A}$ & $\mathrm{B}$ & $\mathrm{C}$ & $\mathrm{D}$ & \\
\hline Dry matter intake & 4392.90 & 4508.61 & 4349.03 & 4393.27 & 159,45 \\
\hline Organic matter intake & 3810.39 & 3931.80 & 3797.80 & 3868.28 & 138,75 \\
\hline Crude Protein intake & $596.93^{\mathrm{a}}$ & $662.41^{\mathrm{b}}$ & $657.24^{\mathrm{b}}$ & $686.56^{\mathrm{b}}$ & 15,03 \\
\hline Crude fiber intake & 856.76 & 839.36 & 787.04 & 725.42 & 26,17 \\
\hline Ether extract intake & 482.82 & 559.97 & 590.49 & 633.79 & 20,80 \\
\hline Energy intake, kcal/day & $15969.38^{\mathrm{a}}$ & $17503.76^{\mathrm{b}}$ & $16856.83^{\mathrm{ab}}$ & $17880.57^{\mathrm{b}}$ & 591,88 \\
\hline
\end{tabular}

$\mathrm{A}=$ ration containing $2051.41 \mathrm{kcal} \mathrm{ME} / \mathrm{kg}: 12.04 \% \mathrm{CP}$

$\mathrm{B}=$ ration containing $2107.79 \mathrm{kcal} \mathrm{ME} / \mathrm{kg}: 13.05 \% \mathrm{CP}$

$\mathrm{C}=$ ration containing $2194.06 \mathrm{kcal} \mathrm{ME} / \mathrm{kg}: 14.04 \% \mathrm{CP}$

$\mathrm{D}=$ ration containing $2294.23 \mathrm{kcal} \mathrm{ME} / \mathrm{kg}: 15.09 \% \mathrm{CP}$

Superscripts with different small letters in the same row indicate significant difference $(\mathrm{P}<0.05)$

SEM = "Standard Error of the Treatment Means" 
The acceleration of growth before puberty is useful in decreasing age at first calving. However, it must be accompanied by increased intake of protein. Increasing dietary CP:ME ratios from low to high dietary CP:ME ratio groups (10.59 to $13.38 \mathrm{~g} / \mathrm{MJ})$ significantly increased CP intake from 0.88 to $1.16 \mathrm{~kg} / \mathrm{day}$ (Dong et al., 2017). Some research resulted that in rapidly growing pre-pubertal heifers, insufficient crude protein content in diet may impair mammary development and decrease first lactation yield (Lohakare et al., 2012). That's why in this study, increasing energy ration followed by increasing $\mathrm{CP}$ on diet. According to Brown et al. (2005), heifers can be given a type of feed to accelerated the growth rate before puberty. This will decrease the age of the first calf in addition to reduced cost of increasing replacement heifers.

\section{Rumen Fermentation Products}

Concentrations of mean ruminal $\mathrm{pH}$ and $\mathrm{N}-\mathrm{NH}_{3}$, were similar among the four diets (Table 4). The highest total VFA, propionate acid and butyric acid were shown in treatment D: 170.32 $\mathrm{mMol}, \quad 28.52 \mathrm{mMol}$ and $13.70 \mathrm{mMol}$ respectively. Conversely, the higher the energy and protein ration, the concentration of acetic acid, methane and NGR decreases.

Ruminal $\mathrm{pH}$ was mostly affected by type of feed. The $\mathrm{pH}$ of rumen fluid of this study ranged from 6.94 to 7.04 and was not significantly different ( $>>0.05$ ) among all treatment. Increased $\mathrm{ME}$ and $\mathrm{CP}$ ration did not affect $\mathrm{pH}$ of rumen fluid. According to Kamra (2005), the optimum $\mathrm{pH}$ for growth of rumen microbes is $6-6.9$, and the normal $\mathrm{pH}$ of rumen fluid is 6-7 (Chiba, 2009).

The protein degradation in rumen resulting among athers $\mathrm{N}-\mathrm{NH}_{3}$. Increased dietary protein did not cause an increase in $\mathrm{N}^{-\mathrm{NH}_{3}}$ concentrations. This is probably due to the $\mathrm{N}$ $\mathrm{NH}_{3}$ resulted in treatment the $\mathrm{B}, \mathrm{C}$ and $\mathrm{D}$ has been used for microbial protein synthesis. This is evident from the MPS in Bali cattle heifers received ration $\mathrm{B}, \mathrm{C}$ and $\mathrm{D}$ increased significantly ( $\mathrm{P}<0.05)$ compared to treatment A (Table 5). According to McDonald et al. (2010) optimal $\mathrm{N}-\mathrm{NH}_{3}$ concentrations for rumen microbial protein synthesis range from 6-21
mMol. The main factor influencing the use of $\mathrm{N}$ $\mathrm{NH} 3$ is the availability of carbohydrates in the ration which serves as an energy source for microbial protein synthesis. The availability of energy in rations $\mathrm{B}, \mathrm{C}$ and $\mathrm{D}$ is higher than that of ration A. Rumen degradable protein and soluble carbohydrates also contribute to the increase in VFA concentrations. Increasing in carbohydrates availability followed by a decrease in ammonia production is a direct incorporation of amino $\mathrm{N}$ into the microbial protein (Jasim et al., 2015).

The treatment $\mathrm{D}$ resulted highest total VFA $(\mathrm{P}<0.05)$ i.e. $170.32 \mathrm{mMol}$. The main energy source for the ruminants are VFA, which produces by microbial fermentation in the rumen. The kind of VFA formed in the rumen affected by type of substrate fermented from feeds, microbial population in the rumen, and rumen environment (Bannink et al., 2008). The increase in VFA concentration is not only due to the increased energy content of the ration, but also due to the increased protein content of the ration. Protein in the rumen, besides being degraded to $\mathrm{N}-\mathrm{NH}_{3}$ for the needs of rumen microbial synthesis will also produce VFA as an energy source (Rodrigues et al., 2007). The total VFA concentration of this study was less than that of Suryani et al., (2019) in male bali fed rations containing $12 \% \mathrm{CP}$ and $3300 \mathrm{kcal} \mathrm{GE} / \mathrm{kg}$ resulting in a total VFA of 192.72-220.71 mMol.

Generally, the proportion of acetic acid: propionic acid: butyric acid in the provision of more fiber feed was 70:20:10 (France and Dijkstra, 2005). According to Chiba (2009), in forage feed, the ratio of acetic acid: propionic acid: butyric acid is $65 \%: 20 \%: 12 \%$. The results of this study get a comparison of 73:16:11 (Treatment A); 67:20:13 (Treatment B); 64:24:12 (Treatment C) and 57:29:14 (Treatment D). This means that ration $\mathrm{D}$ is the most glycogenic diet. This is also supported by the lowest methane production in treatment D. Propionic acid is a substrate for gluconeogenesis. Acetic acid and butyric acid through oxidation in the citric acid cycle are mainly used as energy sources by host animals. Acetic acid is also an important substrate for lipogenesis (France and Dijkstra; 2005). 
Table 4. Rumen fermentation products of Bali cattle heifers age of 18 months

\begin{tabular}{|c|c|c|c|c|c|}
\hline \multirow{2}{*}{ Variables } & \multicolumn{4}{|c|}{ Treatments } & \multirow{2}{*}{ SEM } \\
\hline & A & $\mathrm{B}$ & $\mathrm{C}$ & $\mathrm{D}$ & \\
\hline $\mathrm{pH}$ of rumen fluid & 6.94 & 7.03 & 7.04 & 7.01 & 0.08 \\
\hline $\mathrm{N}-\mathrm{NH}_{3}(\mathrm{mMol})$ & 12,11 & 11,91 & 11,96 & 12,04 & 0.09 \\
\hline VFA Total (mMol) & $163.16^{\mathrm{a}}$ & $164.62^{\mathrm{a}}$ & $161.08^{\mathrm{a}}$ & $170.32^{\mathrm{b}}$ & 7.33 \\
\hline \multicolumn{6}{|l|}{ VFA partial in $100 \mathrm{mMol}$} \\
\hline Acetate (mMol) & $73.29^{\mathrm{a}}$ & $67.60^{\mathrm{a}}$ & $64.30^{\mathrm{ab}}$ & $57.77^{\mathrm{b}}$ & 2.95 \\
\hline Propionate (mMol) & $16.01^{\mathrm{a}}$ & $19.64^{\mathrm{b}}$ & $24.20^{\mathrm{c}}$ & $28.52^{\mathrm{d}}$ & 1.21 \\
\hline Butyrate (mMol) & $10.70^{\mathrm{a}}$ & $12.76^{\mathrm{b}}$ & $11.51^{\mathrm{b}}$ & $13.70^{\mathrm{b}}$ & 0.36 \\
\hline Methane (mMol) & $24.46^{\mathrm{a}}$ & $27.19^{\mathrm{a}}$ & $21.81^{\mathrm{ab}}$ & $18.38^{\mathrm{b}}$ & 1.56 \\
\hline Non Glycogenic Ratio & $6.40^{\mathrm{a}}$ & $4.89^{\mathrm{b}}$ & $3.92^{\mathrm{b}}$ & $3.07^{\mathrm{b}}$ & 0.46 \\
\hline
\end{tabular}

$\mathrm{A}=$ ration containing $2051.41 \mathrm{kcal} \mathrm{ME} / \mathrm{kg}: 12.04 \% \mathrm{CP}$

$\mathrm{B}=$ ration containing $2107.79 \mathrm{kcal} \mathrm{ME} / \mathrm{kg}: 13.05 \% \mathrm{CP}$

$\mathrm{C}=$ ration containing $2194.06 \mathrm{kcal} \mathrm{ME} / \mathrm{kg}: 14.04 \% \mathrm{CP}$

$\mathrm{D}=$ ration containing $2294.23 \mathrm{kcal} \mathrm{ME} / \mathrm{kg}: 15.09 \% \mathrm{CP}$

Superscripts with different small letters in the same row indicate significant difference $(\mathrm{P}<0.05)$

SEM = "Standard Error of the Treatment Means"

\section{Microbial Protein Synthesis}

One possible solution for increasing MPS is synchronizing the two of rumen degradable proteins (RDP) of both non-protein nitrogen and true protein with an energy ratio (Seo et al., 2010). Microbial protein synthesis was affected by the level of DOMR. Ration containing $2294.23 \mathrm{kcal}$ ME/kg: $15.09 \%$ CP (Treatment D) resulted highest intake energy, protein and DOMR. Increased energy and protein intake causes an increase in rumen fermentation. One indicator of increased rumen fermentation can be seen from MPS. The results of this study showed the highest MPS $(\mathrm{P}<0.05)$ in treatment D was $562.06 \mathrm{~g} /$ day (Table 5). These results are slightly higher than Suryani et al. (2019) that fed male Bali cattle rations containing GE $3297 \mathrm{kcal} / \mathrm{kg}$ and $11.54 \%$ protein produced MPS $552.21 \mathrm{~g} / \mathrm{d}$.

One of important limiting factors for animal performance is the daily amount of absorbable amino acids (AA) in their small intestine. Amino acids that enter the small intestine are microbial proteins, non-degraded feed proteins or bypass protein, amino acids and peptides from diets that escape degradation, and endogenous secretions. Microbes produced in the rumen can supply 60 to $80 \%$ of the amino acids absorbed from the small intestine. The efficiency of microbial protein synthesis is a major factor affecting the overall amino acid requirement of ruminants (Jasim et al., 2015).

Table 5. Microbial protein synthesis of Bali cattle heifers age of 18 months

\begin{tabular}{|c|c|c|c|c|c|}
\hline \multirow{2}{*}{ Variables } & \multicolumn{4}{|c|}{ Treatments } & \multirow{2}{*}{ SEM } \\
\hline & A & $\mathrm{B}$ & $\mathrm{C}$ & $\mathrm{D}$ & \\
\hline DOMR (g/day) & $2596,60^{\mathrm{a}}$ & $2653,41^{\text {ab }}$ & $2748,98^{\mathrm{bc}}$ & $2810,30^{\mathrm{c}}$ & 164.75 \\
\hline Microbial nitrogen ( $\mathrm{g} /$ day) & 83,09 & 89,17 & 83,70 & 89,93 & 5.27 \\
\hline MPS (g/day) & $519,32^{\mathrm{a}}$ & $537,35^{\mathrm{ab}}$ & $546,46^{\mathrm{b}}$ & $562,06^{\mathrm{b}}$ & 7.30 \\
\hline Purine absorption (mMol) & $114,29^{\mathrm{a}}$ & $122,66^{\mathrm{a}}$ & $115,13^{\mathrm{b}}$ & $123,70^{\mathrm{b}}$ & 7.25 \\
\hline Purine derivate excretion (mMol) & 118,96 & 126,65 & 119,80 & 127,79 & 6.64 \\
\hline Allantoin urine excretion (mMol) & 101,11 & 107,65 & 101,83 & 108,62 & 5.65 \\
\hline MPS efficiency ( $\mathrm{g} / \mathrm{kg}$ OM intake) & 135,13 & 140,11 & 137,22 & 145,20 & 5.09 \\
\hline Protozoa $\left(10^{6} / \mathrm{ml}\right.$ rumen fluid $)$ & $1.15^{\mathrm{a}}$ & $1.89^{\mathrm{b}}$ & $1,70^{\mathrm{b}}$ & $1.68^{\mathrm{b}}$ & 0.53 \\
\hline
\end{tabular}

$\mathrm{A}=$ ration containing $2051.41 \mathrm{kcal} \mathrm{ME} / \mathrm{kg}: 12.04 \% \mathrm{CP}$

$\mathrm{B}=$ ration containing $2107.79 \mathrm{kcal} \mathrm{ME} / \mathrm{kg}: 13.05 \% \mathrm{CP}$

$\mathrm{C}=$ ration containing $2194.06 \mathrm{kcal} \mathrm{ME} / \mathrm{kg}: 14.04 \% \mathrm{CP}$

$\mathrm{D}=$ ration containing $2294.23 \mathrm{kcal} \mathrm{ME} / \mathrm{kg}: 15.09 \% \mathrm{CP}$

Superscripts with different small letters in the same row indicate significant difference $(\mathrm{P}<0.05)$

SEM = "Standard Error of the Treatment Means" 
Table 6. Performances of Bali cattle heifers age of 18 months

\begin{tabular}{|c|c|c|c|c|c|}
\hline \multirow{2}{*}{ Variables } & \multicolumn{4}{|c|}{ Treatments } & \multirow{2}{*}{ SEM } \\
\hline & A & B & $\mathrm{C}$ & $\mathrm{D}$ & \\
\hline Initial body weight, $\mathrm{kg}$ & 192 & 193,67 & 193,67 & 194,33 & 4,92 \\
\hline Final body weight, $\mathrm{kg}$ & 217,93 & 225,62 & 219,67 & 228,94 & 7,57 \\
\hline Daily weight gain, $\mathrm{kg}$ & $0,32^{\mathrm{a}}$ & $0,39^{\mathrm{b}}$ & $0,32^{\mathrm{a}}$ & $0,42^{\mathrm{b}}$ & 23,59 \\
\hline Feed Conversion Ratio & $15.31^{\mathrm{b}}$ & $11.80^{\mathrm{a}}$ & $14.90^{\mathrm{b}}$ & $10.76^{\mathrm{a}}$ & 0,77 \\
\hline
\end{tabular}

$\mathrm{A}=$ ration containing $2051.41 \mathrm{kcal} \mathrm{ME} / \mathrm{kg}: 12.04 \% \mathrm{CP}$

$\mathrm{B}=$ ration containing $2107.79 \mathrm{kcal} \mathrm{ME} / \mathrm{kg}: 13.05 \% \mathrm{CP}$

$\mathrm{C}=$ ration containing $2194.06 \mathrm{kcal} \mathrm{ME} / \mathrm{kg}: 14.04 \% \mathrm{CP}$

$\mathrm{D}=$ ration containing $2294.23 \mathrm{kcal} \mathrm{ME} / \mathrm{kg}: 15.09 \% \mathrm{CP}$

Superscripts with different small letters in the same row indicate significant difference $(\mathrm{P}<0.05)$

SEM = "Standard Error of the Treatment Means"

\section{Performances}

Overall finding of this study is that the increase $\mathrm{ME}$ and $\mathrm{CP}$ level improved the performance of Bali heifer age of 18 months. As we understand, the quality of ruminant livestock feed is determined by its digestibility. The digestibility of the feed is depend on chemical composition of the feed and the crude fiber intake. Crude fiber in ruminant livestock ration is essential to keep the rumen condition healthy and support the synthesis of microbial proteins.

The results of this study on Bali heifer age of 18 months is much lower than that of other cattle. Research conducted by Devant et al. (2000) in Friesian crossbred heifers given rations containing $14.4 \%$ crude protein result DOM 3.2 $\mathrm{kg} / \mathrm{d}$, protein intake $602.5 \mathrm{~g} / \mathrm{d}$, DMI $4.49 \mathrm{~kg} / \mathrm{d}$ and generate Average Daily Weight Gain 1.21 $\mathrm{kg} / \mathrm{d}$. Feeding dairy heifers a balanced diet is always important. Dong et al. (2017) recommended ration contain 14 to $15 \% \mathrm{CP}$ for pre-pubertal heifers based on $2.15 \% \mathrm{BW} \mathrm{DMI} / \mathrm{d}$ and energy to allow 1.75 to 2.00 pounds of average daily weight gain or about $130 \mathrm{kcal}$ of metabolizable energy (ME) per pound of metabolic body weight. Brown et al. (2005) fed moderate diet contain $21.3 \% \mathrm{CP}(\mathrm{M}=$ moderate protein and energy intake) and high diet contain $30.3 \% \mathrm{CP}(\mathrm{H}=$ high protein and energy intake $)$ to female Holstein calves. The result that ADG and DMI heifer calves fed $\mathrm{M}$ diet respectively 0.379 $\mathrm{kg} / \mathrm{d}$ and $0.847 \mathrm{~kg} / \mathrm{d}$ compared with $\mathrm{H}$ diet respectively $0.668 \mathrm{~kg} / \mathrm{d}$ and $1.213 \mathrm{~kg} / \mathrm{d}$. This result indicate that fed the calves with high diet at the beginning period will reduce growth rate after weaning. The recommended rate of gain after weaning is $800-1000 \mathrm{~g} / \mathrm{d}$. To achieve younger ages at puberty and first calving in dairy heifers, the pre weaning period offers potential to increase body growth rates through increased energy and protein intake without causing excess fattening (Brown et al., 2005).

Growth rate of F1 Angus $x$ Chinese Xiangxi yellow cattle were unaffected by dietary energy (TDN: $80 \%$ vs 70\%) and protein levels (14.3\% vs $11.9 \%$ ). Fed high energy (TDN $80 \%$ ) diet had a significantly lower DMI (6.76 vs. 7.48 $\mathrm{kg} \mathrm{DM} / \mathrm{d}, \mathrm{P}<0.01)$ and FCR (9.38 vs. 11.13, $\mathrm{P}<$ 0.01 ) than those fed low energy (TDN 70\%) diet. Energy and protein levels were not affected the ADG and final body weight. Compared with the low energy (TDN 70\%: CP 11.9) diet, the high energy (TDN 80\% : CP 14.3\%) group had ADG $0.77 \mathrm{vs} 0.71 \mathrm{~kg} / \mathrm{d}$ and final body weight 410.44 vs $399.17 \mathrm{~kg}$ (Li et al., 2014). The relationship between protein intake with average daily gain following the equation $\mathrm{Y}=0.2363 \mathrm{X}+191.44$ where $\mathrm{Y}=$ Average Daily Gain $(\mathrm{g} / \mathrm{d})$ and $\mathrm{X}=$ Protein intake $(\mathrm{g} / \mathrm{d})$ with $\mathrm{R}^{2}=0.80739$.

\section{CONCLUSION}

Based on these results it can be concluded that ration containing $2294.23 \mathrm{kcal}$ $\mathrm{ME} / \mathrm{kg}$ and $15.09 \% \mathrm{CP}$ will improve nutrient intake, increasing rumen fermentation, microbial protein synthesis and ending on improving weight gain of Bali cattle heifer age of 18 months.

\section{ACKNOWLEDGEMENTS}

The authors would like to thank Directorate General of Higher Education, Ministry of Education and Culture of Indonesia, for supporting this research through the University Excellent Research (PUPT) Competitive Research Grant 2017. 


\section{REFERENCES}

AOAC. 1990. Official Methods of Analysis. Association of Official Agricultural Chemists. Washington, D.C. 15th (1): 136-138.

Banning, A., J. France, S. L.pez, W. J. J. Gerrits, E. Kebreab, S. Tamminga, and J. Dijkstra. 2008. Modelling the implications of feeding strategy on rumen fermentation and functioning of the rumen wall. Anim. Feed Sci. Technol. 143 Issue (1-4): 3-26.

Bhatti, S. A., M. Sarwar, M. S. Khan, and S. M. I. Hussain. 2007. Reducing the age at first calving through nutritional manipulations in dairy buffaloes and cows: A Review, Pakistan Veterinary Journal, 27 (1): 42-47.

Brown, E. G., M. J. VandeHaar, K. M. Daniels, J. S. Liesman, L. T. Chapin, D. H. Keisler, and M. S. Weber Nielsen. 2005. Effect of Increasing Energy and Protein Intake on Body Growth and Carcass Composition of Heifer Calves. J. Dairy Sci. 88: 585-594.

Chen, X. B. and M. J. Gomes. 1995. Estimation of microbial protein supply to sheep and cattle basid on urinary excretion of purine derivatives-an overview of the technical details. Ocasional publication. Buchsburnd, Aberdeen: Ed. Rowett Research Institute. (September 1995), p.21.

Chiba, L. 2009. Animal Nutrition Handbook Second Revision. Available from: https://umkcarnivores3.files.wordpress. com/2012/02/animal-nutrition2.pdf.

Chumpawadee, S., K. Sommart, T. Vongpralub and V. Pattarajinda. 2006. Effects of synchronizing the rate of dietary energy and nitrogen release on ruminal fermentation, microbial protein synthesis, blood urea nitrogen and nutrient digestibility in beef cattle. Asian-Aust. J. Anim. Sci. 19: 181-188.

Devant, M., A. Ferret, J. Gasa, S. Calsamiglia, and R. Casals. 2000. Effects of protein concentration and degradability on performance, ruminal fermentation, and nitrogen metabolism in rapidly growing heifers fed high concentrate diets from 100 to $230 \mathrm{~kg}$ body weight. J. Anim. Sci. 78 (6): 1667-1676.

Dong, L. F., W. B. Zhang, N. F. Zhang, Y. Tu and Q. Y. Diao. 2017. Feeding different dietary protein to energy ratios to Holstein heifers: effects on growth performance, blood metabolites and rumen fermentation parameters. J. of Anim. Physiology and Anim. Nutrition 101: 30-37.

France, J. and J. Dijkstra. 2005. Volatile Fatty Acid Productions. In: Quantitative Aspect of Ruminant Digestion and Metabolism. 2nd Ed. C. A. B. International, Cambridge, USA. Available from: doi:10.1079/9780851998145.0000.

Hristov, A. N., R. P. , Etter, J. K. Ropp, and K. L. Grandeen. 2004. Effect of dietary crude protein level and degradability on ruminal fermentation and nitrogen utilization in lactating dairy cows. J. Anim. Sci. 82: 3219-29.

Jasim, U, M., K. Z. Haque, K. M. Jasimuddin and K. M. M. Hasan. 2015. Dynamics of microbial protein synthesis in the rumen - A Review. Annals of Veterinary and Animal Science. V: 2 (5) : 116-131.

Kamra, D. N. 2005. Rumen microbial ecosystem. Special Section: Microbial Diversity. Current Science, Vol. 89 No. 1:124135.

Karsli, M. A. and J. R. Russell. 2001. Effect of some dietary factors on ruminal microbial protein synthesis. Turk. J. Vet. Anim. Sci. 25 (2001) 681-686.

Li, L., Y. Zhu, X. Wang, Y. He and B. Cao. 2014. Effects of different dietary energy and protein levels and sex on growth performance, carcass characteristics and meat quality of $\mathrm{F} 1$ Angus $\mathrm{x}$ Chinese Xiangxi yellow cattle. Journal of 
Animal Science and Biotechnology 5: 21.

Lohakare, J. D., K. H. Südekum and A. K. Pattanaik. 2012. Nutrition-induced Changes of Growth from Birth to First Calving and Its Impact on Mammary Development and First-lactation Milk Yield in Dairy Heifers: A Review. Asian-Aust. J. Anim. Sci. 25:13381350.

McDonald, P. R., A. Edwards, J. F. D. Greenhalg and C. A. Morgan. 2010. Animal Nutrition 6th Edition. Longman Scientific and Technical Co. Published in The United States with John Willey and Sons Inc, New York.

Migliano, M. E. D. A., C. Silano, C. M. M. R. Martins, M. A. Arcari and M. V. Santos .2016. Efeito da fonte de nitrogênio e teor de proteína bruta da dieta sobre o balanço de nitrogênio e o desempenho produtivo de vacas leiteiras. Brazilian Journal of Veterinary Research and Animal Science. 53 (1): 72-87. doi:10.11606/issn.1678-4456.v53i1p7287.

Pathak, A. K. 2008. Various factors affecting microbial protein synthesis in the rumen (Review). Journal of veterinary world 1(6): 186-189.

Rodríguez, R., A. Sosa, and Y. Rodríguez. 2007. Microbial protein synthesis in rumen and its importance to ruminants. Cuban Journal of Agricultural Science. 41 (4): 287-294.

Schwab, C. G. and G. A. Broderick. 2017. A 100-Year Review: Protein and amino acid nutrition in dairy cows. Journal of Dairy Science. 100:12. Available from: doi:10.3168/jds.2017-13320.

Seo, J. K. , M. H. Kim, J. Y. Yang, H. J. Kim, C. H. Lee, K. H. Kim and K. H. Jong. 2013. Effects of synchronicity of carbohydrate and protein degradation on rumen fermentation characteristics and microbial protein synthesis. AsianAustralasian Journal of Animal Sciences. 26 (3) : 358-365. Available from: doi:10.5713/ajas.2012.12507.

Solorzano, I. 1969. Determination of ammonia in natural seawater by the phenolhypochlorite method. Limnology and Oceanography. 14 (5): 799-801. Available from: doi:10.4319/lo.1969.14.5.0799.

Suryani, N. N., I G. Mahardika, I.W. Suarna, and N. P. Sarini. 2019. Increased gliricidia sepium in ration containing rice straw on rumen fermentation and microbial protein synthesis of indigenous Bali cattle. Advances in Animal and Veterinary Sciences, 7: 193-199. DOI: http://dx.doi.org/10.17582/journal.aavs/ 2019/7.3.193.199

Steel, R. G. D. And J. H. Torrie. 1995. Priciples and Procedures of Statistic. McGrawHill Book Co. Inc., New York.

Xu, J., Yujie Hou, Hongbo Yang, Renhuang Shi, Caixia Wu, Yongjiu Huo, and Guoqi Zhao. 2014. Effects of Forage Sources on Rumen Fermentation Characteristics, Performance, and Microbial Protein Synthesis in Midlactation Cows. Asian Australias. J. Anim. Sci. 27 (5): 667-673. 